\title{
A Breakthrough for Cross-Border Mergers in Europe?
}

\author{
Otmar Thömmes, Deloitte \& Touche GmbH, Munich, Germany
}

The final adoption by the Council on 17 February 2005 of the Commission's proposal to amend and update the EC Merger Directive has raised hopes that crossborder mergers of companies in the EU will, for the first time in European legal history, become a realistic option. Questions do remain unanswered, however, such as whether existing obstacles to mergers in Europe really have been removed and whether the business community will actually make use of the new legal possibilities offered by the amended Directive.

To answer these questions, it is worth reflecting briefly on the protracted history of European tax and legal developments relating to cross-border mergers. The efforts to create single market conditions allowing for companies incorporated under the laws of one EU Member State to merge with companies in another Member State go back to the early 1960s. These efforts were based on the ambitious goal of allowing European businesses to grow beyond national boundaries and to achieve a size competitive with the major players from jurisdictions outside the EU (e.g. the US and Japan). Although the requisite corporate law and tax instruments at the Community level were drafted and presented by the Commission almost simultaneously, the tax framework provided by the EC Merger Directive of 23 July 1990 outdistanced corporate law developments, becoming legally binding on Member States as from 1 January 1992. Because of the lack of corresponding company law provisions on cross-border mergers of companies, the scope of application of merger transactions under the Merger Directive (as defined in Art. 2 lit. a) continued to be fairly minimal in practice despite the tax deferral relief provided by the Directive for these types of crossborder transactions.

The gap between the Merger Directive and company law provisions was closed on 8 October 2004 when the European Company (SE) statute entered into effect. The SE statute allows companies of different Member States to merge provided they are in the legal form of a stock corporation and, as a result of the merger, the receiving company adopts the legal form of an SE. Many observers, including this author, initially believed that 8 October 2004 also marked the start of a new era for European businesses in which cross-border growth by means of mergers would become a readily available option. Disillusionment followed when it became apparent that the legal and tax authorities of the Member States were taking a rather formalistic position towards the SE in deciding whether the SE is entitled to the tax benefits of the Merger Directive. The authorities argued that, because the SE was not specifically listed in the annex to Art. 3 lit. a of the Directive (which defines the Directive's personal scope of application), it was not eligible for deferral relief under the Directive. The Merger Directive, including the annex, was adopted in 1990 - before the SE-Statute had been enacted. In the view of this author, a simple statement by the Commission that the SE is clearly covered under the Merger Directive would have sufficed to clarify the situation. This position is supported by the fact that Art. 10 of the SE Regulation states that the SE must be treated by the Member States like a stock corporation. Because stock corporations always have been listed as eligible entities for purposes of the Merger Directive, the issue could have been resolved without undue delay.

The final version of the Merger Directive, as amended by the Council decision of 17 February 2005, officially includes the SE in the annex to Art. 3 lit. a. Although this amendment was a pure formality and implementation laws easily could have been drafted immediately after the SE Statute was adopted by the Council, the amended Merger Directive grants Member States additional time (until 1 January 2006) to draft the requisite implementation laws.

Currently, only a few Member States have commenced the legislative drafting process. Pending the adoption of corresponding national implementation laws, companies wishing to enter into a cross-border merger in Europe are again relegated to a holding pattern. It may be possible, as established by the European Court of Justice (ECJ), to rely directly on a Directive in the case of delayed implementation by Member States, but such reliance is unlikely because the amount of built-in gains to be disclosed in a crossborder merger is usually very significant and no corporate tax director would be willing to sign off on a transaction of such magnitude without full legal clarity of the company and tax law implications in the countries where the companies involved have been incorporated.

In addition to having to wait until Member States adopt the requisite implementation laws for crossborder mergers, the practical application of the Merger Directive suffers from another obstacle that is more difficult to eliminate: a business-unfriendly attitude held by the tax authorities of many Member States towards companies seeking relief under the Directive. The overriding concern of these tax inspectors seems 
to be the possibility that built-in gains in the assets of the transferring company that accumulated before the cross-border transaction could become unavailable as a source of tax revenue for the state of the transferring company as a consequence of the merger. None of the Member States seems to view the new European framework for cross-border mergers as a potential means of allowing European companies to grow and to create additional tax revenue by virtue of being more successful on a global scale.

In addition to the adoption of the necessary national implementation laws, the tax authorities' day-to-day handling of relief administration under the Merger Directive will be critical in shaping the willingness of European businesses to take advantage of the new legal possibilities provided by the amended Directive.

The examples of implementation laws for the two types of transactions under the Merger Directive (i.e. transfers of assets and exchanges of shares) are interesting. A number of Member States (e.g. Denmark, Ireland and Germany) have included time limits in their implementation laws that impose restrictions on future intragroup restructuring following a transaction for which tax deferral relief has been obtained under the Merger Directive. These time limits, which range between three and seven years, are clearly incompatible with the ECJ's decision in the 1997 Leur-Bloem case, the first ECJ case involving the Merger Directive.

Another impediment to cross-border transfers and share-for-share exchanges is evidenced in the German implementation law. Under the German law, tax neutrality at the level of the transferring company is dependent on the foreign recipient company adopting, for the valuation of the assets or shares transferred to it, the former German tax book value of the transferred assets or shares. In its initial proposal of 17 October 2003, the Commission proposed a solution to the valuation issue regarding cross-border asset transfers and share-for-share exchange transactions. In the final version of the amended Merger Directive, however, the Council removed this provision.

In summary, a true breakthrough for cross-border mergers in Europe awaits the speedy implementation of a legislative framework by the EU Member States to fully implement the Merger Directive, as well as a change in the attitude of the tax authorities towards cross-border transactions. As long as the tax authorities view cross-border transactions within Europe as a threat rather than a business opportunity, companies in Europe are unlikely to effectively make use the opportunities provided by the amended Merger Directive. 